\title{
Rationality, Animality, and Human Nature: Reconsidering Kant's View of the Human/Animal Relation
}

David Alexander Craig

University of Oregon

Kant is often criticized for his strict separation of humans and animals as categorically distinct entities. This separation hinges on the fact that, for Kant, humans are rational, while non-human animals are wholly irrational. This essay argues that a strict separation of rational humanity and irrational animality, prominent in many areas of Kant's thinking, does not characterize his view of the human/animal relation overall. For, within Kant's theory of human nature, rationality and animality are in fact entwined, with both contributing to the goodness and full realization of human life. Through engagement with a range of Kant's writings on human nature, it is suggested that Kant's view of the human/animal relation merits reconsideration by Kant scholars and animaloriented philosophers alike.

David Alexander Craig is a doctoral candidate in the philosophy department at the University of Oregon and a visiting graduate student in the philosophy department at Johns Hopkins University. He is co-founder of the University of Oregon's Human/Animal Research Interest Group and has presented his research at many conferences, including the International Association for Environmental Philosophy, the Society for Phenomenology and Existential Philosophy, and the Ancient Philosophy Society. Several of his essays are forthcoming as peer-reviewed articles or book chapters. His dissertation provides a systematic analysis of the role of animality in Kant's philosophy, particularly in his theory of human nature. He is also currently editing, with Ted Toadvine, a volume on Derrida's The Beast and the Sovereign seminars, and producing, with Anna-Lisa Baumeister, a new translation of Friedrich Schiller's "Über den Zusammenhang der tierischen Natur des Menschen mit seiner geistigen."

\section{Introduction}

In this essay, I attempt to show that Kant's view of the human/animal relation has largely been simplified and misunderstood by Kant's contemporary readers.

Whereas those interested in Kant's view of this relation have primarily attended to his ethical writings, a recent and growing body of literature suggests that Kant's theory of human nature, which is principally developed outside of the critical project and external to the ethical writings, provides the anthropological, 
political, and pedagogical underpinnings needed to fully understand the claims Kant makes about human conduct in the ethical writings and elsewhere. I submit that those interested in Kant's view of the human/animal relation ought likewise turn to Kant's theory of human nature, for there the stakes of Kant's understanding of humanity in relation to animality are powerfully drawn.

At the heart of this theory of human nature is the relation between rationality and animality. Whereas Kant places rationality at the center human nature in a number of ways in a number of texts, he also emphasizes the centrality of animality to the same. That is, Kant accepts it as factual that human beings remain animals, and, in my view, much of what is most remarkable and worth considering in Kant today is precisely his attempt to grapple with and come to terms with this fact. It is at just these moments that his view of the human/animal relation becomes more subtle and interesting than it has been taken to be by commentators, and it is here that the entwined relation of rationality and animality comes to the fore in the Kantian text.

In what follows, I first briefly explicate Kant's view of human/animal difference, which is largely developed in his ethical writings and which has received the most attention from commentators. I then examine, in three steps, Kant's account of human animality as a component of his broader theory of human nature, which has only recently begun to receive sustained scholarly attention, at least in English speaking circles. Whereas rationality and animality are kept neatly distinct in the former view, in the later account rationality and animality enter into a much more delicate tension - with both contributing to the 
goodness and realization of human life. I conclude that the entwined relation of rationality and animality found in Kant's theory of human nature qualifies the stark separation of rationality and animality found in his view of human/animal difference, therefore calling for reconsideration of Kant's broader view of the human/animal relation by Kant scholars and animal-oriented philosophers alike.

\section{Kant's View of Human/Animal Difference}

On multiple levels, Kant sees humans and animals to be definitively, neatly distinct. The central distinction, though, is the fact that, for Kant, humans are rational or possessed of reason, while animals are irrational or devoid of reason. This distinction grounds other important distinctions, such as that between moral or nonmoral status, ends and means, and personhood and "thingness." In the Groundwork for the Metaphysics of Morals, Kant states:

Now I say that the human being and in general every rational being exists as an end in itself, not merely as a means to be used by this or that will at its discretion...Beings the existence of which rests not on our will but on nature, if they are beings without reason, still have only a relative worth, as means, and are therefore called things [Sachen], whereas rational beings are called persons because their nature already marks them out as an end in itself. (Kant, Groundwork, 4:428, 79) ${ }^{1}$

And, in the Lectures on Anthropology: 
The fact that the human being can have the representation "I" raises him infinitely above all the other beings on earth. By this he is a person...that is, a being altogether different in rank and dignity from things, such as irrational animals, with which one may deal and dispose at one's discretion. (Kant, L.A., 7, 127)

These claims, which sharply distinguish humans from animals as a matter of fact, are descriptive and tied to the special roles played by reason, personhood, and end-in-itself within Kant's greater system. ${ }^{2}$ In the wake of this descriptive distinction between humans and animals, Kant sets up prescriptive distinctions as well. Here, human/animal difference is inscribed into the fabric of Kant's moral philosophy, particularly in his taxonomy of duties.

Approaching the issue from the angle of harm, Kant believes that we have a direct duty to refrain from harming other rational beings (and on earth this means other human beings), for only they are ends-in-themselves and not to be treated as mere means, while to everything else in the world we might at best have only an indirect duty to refrain from harm. This distinction has recently occupied commentators interested in developing a Kantian position on the moral worth of various entities not traditionally seen as living or rational, such as the environment. ${ }^{3}$ The case of animals, though, has received the most attention. In Kant's Lectures on Ethics, we find the following:

So if a man has his dog shot, because it can no longer earn a living for him, he is by no means in breach of any duty to the dog, since the latter is 
incapable of judgment, but he thereby damages the kindly and humane qualities in himself, which he ought to exercise in virtue of his duties to mankind. (Kant, L.E., 27: 459, 212)

The fact that the dog is incapable of judgment is presented as the crucial feature. This reveals how Kant's prescriptive view of human/animal difference rests on his descriptive view. Or, put differently, Kant's moral view of animals (that they are not worthy of direct moral consideration) rests on his ontological view of animals (that they are irrational creatures lacking the trappings of a reasoned existence, including judgment).

At a moral or prescriptive level, then, it may be said that Kant's view of human/animal difference is that the former are that to which we have direct moral duties, the latter that to which, while we have no direct duties, we ought nonetheless to act with a degree of respect given the way animals reflect, as it were, our own humanity. As with the descriptive dimension of the same difference, Kant manages to draw a tight prescriptive distinction between humans and animals—one that is anchored in the terms of his wider philosophical system, and particularly in the distinction between rationality and irrationality.

\section{Kant's Account of Human Animality in Religion Within the Boundaries of}

\section{Mere Reason}

Kant's view of human/animal difference, however, is not his final word on the human/animal relation. For although the picture of difference he paints is quite 
stark and clear, his account of human animality—of the way in which, despite these differences, humans have something indelibly animalistic about themselves -is rather blurred. Rather than simply positing humanity and animality in opposition to one another, it reveals them to be unhappily but necessarily entwined. Although in many ways this account reinscribes the harshness of the view of human/animal difference onto the human itself, it also opens up, adjacent to this reinscription, a limited space for challenging that very harshness and for reassessing the relation of humans and animals beyond their categorical differences. It is in exactly this space that the relation between rationality and animality in Kant's theory of human nature enacts a sort of critique-or, at least, provides the resources needed to enact a sort of critiqueof the dichotomization of humans and animals found elsewhere in his text and, again, primarily in the ethical writings.

Kant's account of human animality is stated most succinctly in Religion Within the Boundaries of Mere Reason. There, animality is identified as one of three "predispositions" [Anlagen] that make up the larger "original predisposition to good in human nature" (Kant, Religion, 6:26, 74). Kant offers a layered schematism of the human being, speaking of predispositions to "the animality of the human being, as a living being," to "the humanity in [the human being], as a living and at the same time rational being," and, finally, to the "personality [in the human being], as a rational and at the same time responsible being" (Kant, Religion, $6: 26,74)$. Interestingly, the predisposition to animality, though it is the first or deepest layer of the human's original predisposition to good, is not here 
presented, as it often seems to be in Kant's writing, as the source of what is bad or what contradicts that original goodness. Kant says:

All these predispositions in the human being are not only (negatively) good (they do not resist the moral law) but they are also predispositions to the good (they demand compliance with it). They are original, for they belong to the possibility of human nature. The human being can indeed use the first two inappropriately, but cannot eradicate either of the two. (Kant, Religion, 6:28, 76)

It might be said that human animality, in and of itself, is "a good thing." It is, after all, an original component of human nature, part of what we are as humans. In and of itself, animality is not only compatible with the moral law, but even plays a role in "demanding" our "compliance" with it. ${ }^{4}$ Like the other predispositions, it facilitates goodness in the fullest Kantian sense. As David Sussman puts it, for Kant "animality involves a way of seeing such natural impulses and behaviors as part of a rational, purposive whole...the predisposition to animality is not constituted by our inclinations in general, but by those natural appetites that can be understood as serving the good of our biological species, understood not merely as impulse, but as instinct" (Sussman 230). That is, animality in and of itself, which has both individual and species-level variances, is entirely compatible with the Kantian picture of a rational, unified, and good human existence. 
However, when improperly channeled, animality can and does, for Kant, easily become "a bad thing." And such bad channeling can take place on multiple levels. Kant elaborates:

The predisposition to animality in the human being may be brought under the general title of physical or merely mechanical self-love, i.e. a love for which reason is not required. It is threefold: first, for self-preservation; second, for the propagation of the species, through the sexual drive, and for the preservation of the offspring thereby begotten through breeding; third, for community with other human beings, i.e. the social drive. On these three can be grafted all sorts of vices (which, however, do not of themselves issue from this predisposition as a root). They can be named vices of the savagery of nature, and, at their greatest deviation from the natural ends, are called the bestial vices of gluttony, lust and wild lawlessness (in relation to other human beings). (Kant, Religion, 6:26-27, 75)

Kant here provides a threefold structure for understanding the good and the bad of human animality. Animality generally speaking is a matter of irrational (or, more properly and crucially, pre-rational) self-love. This animalistic self-love is expressed in three modes, each having a good side and a bad side, to continue with this simplified terminology. There is the mode of self-preservation, which is good when prudent and healthy, while bad when gluttonous. There is the mode of propagation, sexuality, and breeding, which is good when controlled and 
proper, while bad when lustful. Finally, there is the mode of community, which is good when well-ordered and cosmopolitan, while bad when wildly lawless.

In each mode, human animality manifests itself in its dual nature-as something both good and bad, a constitutive aspect of human goodness that can facilitate human badness. We can further trace this dual nature, and attend specifically to the relation of rationality to animality, by following Kant's theory of human nature as it concerns itself with humans at the individual and specieslevels, respectively.

\section{Kant's Account of Human Animality: Individual Level}

The drive for self-preservation identified above as one mode of the self-love characteristic of human animality appears in Kant's prescriptive moral theory in the guise of "natural impulses" or "natural instincts," which arise from the individual human's animality and threaten to derail one's duties to oneself. Kant explains:

There are impulses of nature having to do with man's animality. Through them nature aims at a) his self-preservation, b) the preservation of the species, and c) the preservation of his capacity to enjoy life, though still on the animal level only...The vices that are here opposed to his duty to himself are murdering himself, the unnatural use of his sexual inclination, and such excessive consumption of food and drink as weakens his capacity for making purposive use of his powers. (Kant, M.M., 6:420, 545) 
Note that these animalistic natural impulses are, again, in and of themselves "good things." They have, however, a vicious side, with suicide, unnatural sexual acts, and excessive eating and drinking being where these impulses may lead the individual. As Patrick Kain remarks, "Our animality is manifested in the fact that our instincts predispose us to certain emotions that can lead us to our instinctual ends independently of our rational reflection" (Kain 243). The key term here is "independently," which suggests not that animality works in direct contrast to rationality, but rather that it has the potential to veer away from those ends imposed by reason.

These same individual vices, more abstractly, parallel the emergence of evil itself, which has both individual and species-level meanings. In this passage, Kant speaks of instincts [Instinkte] rather than impulses [Triebe], as he had done in the passage above:

This predisposition to good, which God has placed in the human being, must be developed by the human being himself before the good can make its appearance. But since at the same time the human being has many instincts belonging to animality, and since he has to have them if he is to continue being human, the strength of his instincts will beguile him and he will abandon himself to them, and thus arises evil, or rather, when the human being begins to use his reason, he falls into foolishness. (Kant, L.P.D.R., 28:1078, 411) 
Here the disconnect between the bare fact of the human's animalistic natural instincts, which he must have "if he is to continue being human," and the initial weakness of his reason in the face of them is seen to be generative of evil, which turns out to be a matter of foolishness. It is significant that evil is not seen to be the fault of human animality per se, though this provides what might be called the impulsive or instinctual momentum behind evil deeds. That Kant rather holds evil to be a function of a certain misuse of reason shows that the relation between rationality and animality is not, for Kant, as simple as the former being esteemed while the latter is disparaged. ${ }^{5}$

This notion of reason's weakness in the face of individual human animality also plays a role in the model of education central to many of Kant's works, including Anthropology from a Pragmatic Point of View. Central to this model is a concept of discipline whereby one endeavors to keep one's animality, which cannot be eradicated, safely at bay. In the Lectures on Pedagogy we find: "In his education the human being must therefore... be disciplined. To discipline means to seek to prevent animality from doing damage to humanity, both in the individual and in society. Discipline is therefore merely the taming of savagery" (Kant, L.P., 9:449, 444).

Put differently, as expressed earlier in these lectures, discipline "changes animal nature into human nature" (Kant, L.P., 9: 441, 437). Though it falls beyond the scope of the present to innumerate those specific disciplinary techniques, to coin a Foucaultian phrase, that Kant recommends to bring about this disciplining of the human, it should be said that each of the vices Kant has above identified 
as stemming from the weakness of reason in the face of animalistic impulses or instincts has its pedagogical solution in discipline. Individual human animality turns out to be a matter of one's animalistic impulses, the control and proper, disciplined channeling of which falls to reason or rationality. When reason fails at this, and it often does, then evil arises. Kantian evil, therefore, amounts to the failure of reason to sufficiently curb the individual's natural animalistic impulses and instincts.

The relation between rationality and animality in the individual human is, then, seen most clearly in Kant's pedagogical writings, which feature, at their core, a concept of discipline. On the one hand, this educational model figures rationality lording over the animality of the individual, and hence discipline itself seems to be something imposed on that animality from without. On the other hand, though, Kant's is a model designed for implementation by a certain type of animal—the human animal. As Robert Louden explains, "Kant's educational theory is directed at one particular species of rational animal the members of which, due to certain root biological facts concerning their makeup, need to be educated" (Louden, Kant's Impure Ethics, 38). From this vantage point, Kantian education is a form of animal education whereby the animality of the disciplined individual is not eliminated, but refined. Commenting on Kant's suggestion that discipline "changes animal nature into human nature" (Kant, L.P., 9: 441, 437), Louden elsewhere remarks:

Changing animal into human nature by no means entails eradicating or demolishing instincts, desires, and inclinations-a radical change of this 
sort would result in beings who were no longer human. Rather, it refers to the ability (an ability which itself is one of humanity's germs or natural predispositions) to control them through the exercise of reason. (Louden, "Becoming Human," 139)

The ability of human rationality to control human animality does not entail the doing away with of such animality, but rather animality's transformation into a carefully curtailed complement of humanity within the nature of the human. At the level of the human individual, this process of control succeeds through the disciplining of instincts and impulses. At the level of the human species, as we shall see next, rationality is likewise engaged in a certain process of refinement vis-à-vis human animality. And while at this larger level evil remains a threatening byproduct of the failure of such refinement, discipline as a specific mode of control exits the Kantian picture.

\section{Kant's Account of Human Animality: Species Level}

In "Idea for a Universal History with a Cosmopolitan Aim," Kant refers to nature's "leading our species from the lowest step of animality gradually up to the highest step of humanity" (Kant, Idea, 8:27, 115). Such statements enlarge animality from a layer of individual human development to a step within the history of the human species. It should be emphasized that in this enlargement animality remains a step within the history of the human species, just as fully formed humanity remains a step within this history. Animality is not, therefore, excluded 
from the history of humanity. Rather, animality and humanity both are steps within the history of the human species. As Susan Meld Shell explains, for Kant the goal of human history "is the simultaneous realization of our animal and human perfections, the two natural ends whose historical and sexual divergence keeps human development in motion" (Shell 213). That is, animality and humanity can be seen as necessary poles of human development, without either of which the movement of such development would come to a halt.

Kant's view of human history is progressive in the sense many postmodern theorists object to, in that human history is seen to be an improvement of the species whereby, for instance, certain forms warfare are seen as "progress." Importantly, human history is also (or perhaps primarily) a story of the emergence and assertion of human reason. Indeed, it is reason that allows the species to achieve humanity in the morally resplendent sense while keeping in check the dangerous tendencies of animality. In other words, for Kant the historical movement of reason is the progress from animality to humanity.

Interestingly, Kant distinguishes between the progressive significance of reason at the species-level, and reason's more mixed legacy at the level of the individual. In "Conjectural Beginning of Human History," he writes:

Nevertheless, this course [of human history], which for the species is a progress from worse toward better, is not the same for the individual. Before reason awoke, there was neither command nor prohibition and hence no transgression; but when reason began its business and, weak as it is, got into a scuffle with animality in its whole strength, then there 
had to arise ills and, what is worse, with more cultivated reason, vices, which were entirely alien to the condition of ignorance and hence of innocence. (Kant, C.B., 8:115, 169)

The metaphor of reason's getting into a "scuffle" with animality and so releasing ills unto the world is highly revealing. It is significant that animality is taken to be, initially at least, stronger than reason or rationality, also that it is reason that, we can presume, initiates the scuffle. "Scuffle," which is the term used in the recent Cambridge translation of "Conjectural Beginning," is also arguably not the best rendering of the German Gemenge. A mixing or melding, as in the bringing together of chaotic elements, would avoid the violent connotations of "scuffle," and so might better capture the nuance of the relation between rationality and animality conveyed in the passage.

The passage also reveals something of the relation between individual human animality and species-level human animality. In both cases, as we saw earlier, animality has a mixed character. It is both "good" and "bad." Here, we see that animality's "bad side," for Kant, is worse with individuals than it is with the species as a whole. While the individual faces a host of problems sourcing from the conflict of his or her animality and his or her rationality (and so must be disciplined), the species has in large part progressed and, Kant hopes, will only continue to progress, beyond the perilous aspects of its animality.

All this yields a curious picture of human nature whereby Kant is quite optimistic about the fate of the human species, while being quite pessimistic 
about the fate of human individuals. At times one senses a genuine anxiety on Kant's part about the threat of animality, so much so that his vision of political organization can often seem singularly designed to mitigate this threat. From the constitutional makeup of civil society to the unruly behavior of the small child, animality plays a critical role in Kant's theory of human nature. Something to be weakened, something to be stepped beyond, something to be disciplined. And yet, it must be recalled, for this is the crux of the ambivalence of Kant's view of the human/animal relation, animality is also something necessary, a component of the possibility of human nature, a sliver, even, of the overall goodness of the human being.

\section{Conclusion}

Many figures in contemporary philosophy have recently turned their attention to animals, animal life, the human/animal relation, and animality. ${ }^{6}$ Matthew Altman, Christine Korsgaard, Holly Wilson, and Allen Wood are among the few who defend Kantian positions regarding animals. Within the broader group of contemporary philosophers who are what might be called "animal-oriented," however, Kant is usually taken as a figure to be rejected, and his thinking on animals and animality is usually quickly dismissed if it is seriously considered at all. $^{7}$

Even so, Kant's overall view of the human/animal relation, and particularly the entwined relation of rationality and animality within his theory of human nature, has the potential to occupy a more substantial place within contemporary 
animal-oriented philosophy. No doubt, given that many ideas directly linked to his theory of human nature are highly problematic by today's standards (the disciplinary model of education, teleological historical progress, hierarchical and value-laden notions of race and gender, etc.) few would accept Kant's account as simply "correct." And yet, in so far as Kant's account of human animality presents a singular figuration of the human/animal relation within the human being, and in so far as this figuration in significant ways runs against Kant's own binary characterization of humans and animals as categorically distinct, then Kant's view of the human/animal relation might yet have something novel to contribute to contemporary debates regarding the nature of rationality and our own curious status as creatures, both human and animal.

${ }^{1}$ In this essay, I use the following abbreviations for references to Kant's works: C.B.- "Conjectural Beginning of Human History" Groundwork-Groundwork of the Metaphysics of Morals Idea- "Idea for a Universal History with a Cosmopolitan Aim" L.A.-Lectures on Anthropology

L.E.-Lectures on Ethics

L.P.-Lectures on Pedagogy

L.P.D.R. - Lectures on the Philosophical Doctrine of Religion M.M. - The Metaphysics of Morals Religion-Religion within the Boundaries of Mere Reason For each reference, I provide the volume and page number from Kant's gesammelte Schriften (Berlin: Walter de Gruyter, 1902-), followed by the page number from the corresponding English translation.

${ }^{2}$ For a succinct treatment of how Kant's view of human/animal difference fits within the architecture of his larger system, see Wilson.

${ }^{3}$ See Altman, esp. Ch. 2, "Kant's Strategic Importance for Environmental Ethics." ${ }^{4}$ Allen Wood confirms this idea in a recent article, arguing that, from Kant's perspective, "Our sensuous or animal nature is innocent, and in itself even something good." Wood, "Kant's Fourth Proposition," 117. ${ }^{5}$ For an elaboration upon this point, see Wood, "Kant's Fourth Proposition," 125; and Wood, Kantian Ethics, 4. 
${ }^{6}$ For a representative sampling of such work from the continental tradition, see Atterton and Calarco. For a smaller sampling of recent work largely from a more mainstream tradition, see Cavell, et al.

${ }^{7}$ Indeed, most animal-oriented philosophers would likely agree with Elizabeth Costello, a central character in J.M. Coetzee's The Lives of Animals, when she says, "[e]ven Immanuel Kant, of whom I would have expected better, has a failure of nerve" at the point of considering the value of animals' lives. Coetzee, 23.

\section{Works Cited}

Altman, Matthew C. Kant and Applied Ethics: The Uses and Limits of Kant's Practical Philosophy. Malden, MA: Wiley-Blackwell, 2011. Print.

Atterton, Peter, and Matthew Calarco, ed. Animal Philosophy. London: Continuum, 2004. Print.

Cavell, Stanley, Cora Diamond, John McDowell, lan Hacking, and Cary Wolfe. Philosophy and Animal Life. New York, Columbia University Press, 2008. Print.

Coetzee, J.M. The Lives of Animals. Princeton, N.J.: Princeton University Press, 2003. Print.

Kain, Patrick. "Prudential Reason in Kant's Anthropology." Essays on Kant's Anthropology. Ed. Brian Jacobs and Patrick Kain. Cambridge: Cambridge University Press, 2003. 230-265. Print.

Kant, Immanuel. "Conjectural Beginning of Human History." Anthropology, History, and Education. Ed. G. Zöller and R. Louden. Cambridge: Cambridge University Press, 2007. 160-175. Print.

—. Groundwork of the Metaphysics of Morals: Practical Philosophy. Ed. M.J. Gregor. Cambridge: Cambridge University Press, 1999. 37-108. Print.

_ - "Idea for a Universal History with a Cosmopolitan Aim." Anthropology, History, and Education. Ed. G. Zöller and R. Louden. Cambridge: Cambridge University Press, 2007. 107-120. Print. 
Lectures on Anthropology. Ed. A. Wood and R. Louden. Cambridge: Cambridge University Press, 2013. Print.

- Lectures on Ethics. Ed. P. Heath and J.B. Schneewind. Cambridge: Cambridge University Press, 1997. Print.

—. Lectures on Pedagogy: Anthropology, History, and Education. Ed. G. Zöller and R. Louden. Cambridge: Cambridge University Press, 2007. 434-485. Print.

- Lectures on the Philosophical Doctrine of Religion: Religion and Rational Theology. Ed. A. Wood and G. Di Giovanni. Cambridge: Cambridge University Press, 2001. 335-452. Print.

—. The Metaphysics of Morals: Practical Philosophy. Ed. M.J. Gregor. Cambridge: Cambridge University Press, 1999. 353-604. Print.

- Religion within the Boundaries of Mere Reason: Religion and Rational Theology. Ed. A. Wood and G. Di Giovanni. Cambridge: Cambridge University Press, 2001. 39-216. Print.

Louden, Robert. "Becoming Human: Kant and the Philosophy of Education." Kant's Human Being: Essays on His Theory of Human Nature. Oxford: Oxford University Press, 2011. 136-149. Print.

—. Kant's Impure Ethics: From Rational Beings to Human Beings. Oxford: Oxford University Press, 2000. Print.

Shell, Susan M. "Kant's 'True Economy of Human Nature': Rousseau, Count Verri, and the Problem of Happiness." Essays on Kant's Anthropology. Ed. Brian Jacobs and Patrick Kain. Cambridge: Cambridge University Press, 2003. 194-229. Print.

Sussman, David. The Idea of Humanity: Anthropology and Anthroponomy in Kant's Ethics. New York: Routledge, 2001. Print.

Wilson, Holly L. "The Green Kant: Kant's Treatment of Animals." Environmental Ethics: Readings in Theory and Application. 6th edition. Ed. Louis P. Pojman and Paul Pojman. Boston: Wadsworth, 2012. 62-70. Print. 
Wood, Allen. Kantian Ethics. Cambridge: Cambridge University Press, 2007. Print.

—. "Kant's Fourth Proposition: The Unsocial Sociability of Human Nature." Kant's Idea for a Universal History with a Cosmopolitan Aim: A Critical Guide. Ed. Amelie Oksenberg Rorty and James Schmidt. Cambridge: Cambridge University Press, 2012. 112-128. Print. 